\title{
THE POLITICS OF PEACE AND CONFLICT IN BOSNIA AND HERZEGOVINA
}

\author{
Muhidin Mulalić \\ International University of Sarajevo, Bosnia and Herzegovina \\ Mirsad Karić \\ International University of Sarajevo, Bosnia and Herzegovina
}

\begin{abstract}
Twenty years after the Dayton Peace Agreement an exclusive ethnic ideology, international tutelage and dependency characterize Bosnia and Herzegovina. Wrong political approaches by the international and local political actors in Bosnia and Herzegovina created permanent crisis, the status quo and a 'case' country. Conflict, furthermore enriched with exclusive ethno-cultural paradigm and the legacy of bloody crucible of the war, shape today's political discourse in Bosnia and Herzegovina. Based on content analysis of leading newspapers, this paper examines the relationship between conflict and peace inclinations of main political leaders among Serbs, Bosniaks and Croats. In order to test the first objective on political discourse and political relationships based on the conflict vs. peace politics, using content analysis, the research analyzed media news on Bosnia and Herzegovina by considering only socio-political topics. We randomly selected 120 news from newspaper namely, Nezavisne novine, Glas srpske, Dnevni list and Dnevni avaz. For testing, the second objective on positive vs. negative political discourse of main political leaders we randomly selected 360 interviewbased news about key political leader including Bakir Izetbegovic (Bosniak), Dragan Čović (Croat) and Milorad Dodik (Serb). Research findings indicated that the conflict politics is deeply rooted in political discourse, media, among political leaders and the public.
\end{abstract}

Keywords: Conflict; Peace Politics; Conflict Politics; Political Participation; Political Leaders; Bosnia and Herzegovina

\section{Introduction}

The Dayton Peace Agreement (DPA), brokered by US diplomat Richard Holbrooke (1998), prevented the continuation of war and destruction, but the political turmoil, ethnic tensions, territorial pretensions and overall an idea that Bosnia and Herzegovina is still a 'case' country or as an 'experiment of the international community', has continued to this very day. The major conflict lines within Bosnian society thus remain essentially unresolved. The ghosts of war, destruction and divisiveness are still hunting the people of Bosnia and Herzegovina and, most probably, the future generations will continue to grapple with the issue of crime and guilt because unresolved past has already shaped people's exclusive ethnic identification. Bosnia and Herzegovina is considered as "a deeply divided society," "ethnic democracy" and an "Ethnopolis" where different ethnic groups, due to strong nationalistic rhetoric and 'ethnopolitics', live isolated from each other (Parish, 2011; Cohen, 1995, Perry, 2005 and Mujkic, 2007). According to the theoretical and conceptual meanings of a sovereign state, Bosnia and Herzegovina remains fragile and unstable state (Trnka, 2000, p. 319 and Šarčević, 2009, p. 12). Therefore, under current circumstances, social-cultural change and an establishment of a viable social order 
and harmony is 'mission impossible'. On the contrary, there is a crisis of democracy and the status quo that produces instability, fear, inter-ethnic distrust and mentality that is entirely based on the conflict and not constructive and realist compromise and a solution (Džihić and Wieser, 2011, pp. 1809-1810).

Considering the Balkans mentality, which is based on the tradition of heroic, warlike and conflicting values; values of peace, dialogue and compromise are perceived as weakness and shameful. Unfortunately, religious traditions, literature, historical works and folklore have been promoting these values for the past few centuries. Actually, all aspects of life are rigidly based on Marxist theory of conflict and nationalist liberation ideologies. Therefore, very few politicians, not only in Bosnia and Herzegovina but in the region, who attempted to use the politics of peace, dialogue and compromise were perceived not only as weak political leaders but very often they were accused of betraying their own people and the nation. For instance, Zoran Đindić was assassinated in Serbia because of his politics of peace and cooperation. These are some of the reasons why European diplomats and policy-makers view the Balkans as

a periphery or the province and one of the biggest obstacles for European stability, peace and security. For this purpose the notion of Balkanization as a geographical and political term, which signifies territorial and political divisiveness, hatred among the people and even apocalyptic devastation, was introduced by Western scholars (Mulalic, 2013, p. 40).

The politics in Bosnia and Herzegovina is far away from the pragmatic and realists perspectives. Political parties and their actors focus on daily political interests that are shaped by ethno-cultural paradigm. There are endless discussions related to the war, ethnic territories, ethnic representation and ethnic culture, language, history and identity. This emphasis puts aside real socio-economic problems and creates artificial ethnic boundaries and barriers between different ethnic groups that are destined to live together. Besides, a serious democratic progress is impossible because of the creation of exclusive ideological difference, politics of fear and deadly threat from the others.

As an alternative, the politics of peace and soft diplomacy should be used as tools to support "soft power potential, generate goodwill, to frame international agenda in particular ways, to erect and re-enact boundaries and/or to create societal linkages across them" (Batora and Mokre, 2011, p. 1). Both local and regional politicians should use the politics of peace and soft diplomacy as to project creative expression in improving mutual understanding within and across state borders. This could strengthen the role of different actors on the local and international political scene (Nye, 2004).

Certainly, culture could be used in determining national and, as well as regional character because of common and shared heritage. Then, due to common historical experience, the people of Bosnia and Herzegovina have natural right to special relations with each other based on historical legacy and cultural similarities. Therefore,

National identity should be derived from shared socio-cultural values while ethnic bonds, should be upheld and broadly respected. The history of Bosnia-Herzegovina indicates that ethnic distinctive bonds have been flourishing throughout centuries while common national identification and a sense of interconnected relationship between diverse groups of people had always been strongly felt. Actually history of Bosnia-Herzegovina points to cultural inclusion and cross-culture, not exclusive cultural isolation. That is why nowadays as throughout the past, although belonging to different groups of people, many distinguished Serbs, Croats and Bosniaks have accepted a common and shared Bosnian national identity (Mulalic, 2014, pp. 63-64).

Regional shared historical and cultural values, if properly and positively perceived, open up many opportunities for cooperation. The political elites have the potential to improve 
furthermore regional cooperation by working together on the common path towards the EU. Balkans cooperation is inevitable from socio-political and economic point of view as "all Balkan states are in the same boat" or to use the classical concept of Keohane and Nye (1970) "all Balkans states are interdependent." Even during the 1990s Balkans trade, communication, energy and security cooperation and interdependence was inevitable. In this regard Bechev (2011) stated:

Beyond doubt, regional interdependence is a factor that matters for the Balkans. Whether they liked it or not, in the 1990s local states found themselves bundled by their politics, security concerns and geography, and to a lesser degree by their economies. Even divisive forces such as the legacies of conflict gave coherence to the notion of one South East Europe. In addition to common threats, interdependence also meant developmental opportunities. If it did not offer an economic structure, shared geography did offer potential gains in sectors such as transport infrastructure and energy (p. 39).

The idea of Europe as an integrated multicultural space is genuine European product. European conception of the balance of power since the times of the Westphalia (1648) made the basis for cultural exchange and cooperation in Europe. In this regard, the Balkans should learn from the European experience and cultural exchange and cooperation should become its future basis. Within the Balkans framework, Bosnia and Herzegovina should

acknowledge the existence of multiple identities that enrich rather than pose a threat to the country. Only such diverse identities can connect citizens of Bosnia and Herzegovina with those of neighboring countries in particular and of the EU in general. Multicultural identity should become a common identity while multiple identities should be cherished by all BosniaHerzegovina citizens. Serious preference should be given to the institutionalized fostering of multiculturalism - not only for the sake of the very survival of Bosnia-Herzegovina as a state but for the survival of global multiculturalism as a whole (Mulalic, 2009, pp. 121-122).

In the age of globalization and in the world of diversity it has become an imperative to foster and preserve tolerance, understanding and co-existence in multicultural and multiethnic societies as an alternative to Huntington's civilizational clash (Mahmut Čehajić, 2000, pp. 88-90). In this regard, the inclusive multicultural model of Bosnia-Herzegovina could position a country as very unique state-model, which other multicultural and multiethnic countries could follow worldwide. This is in particular true for the EU member-states that presently cope with the challenges related to minorities, religion, culture, language and ethnicity.

\section{Methodology}

This paper examines internal relationships based on leading political actors who shape policy and public opinion. It is worth analyzing their public statements on key sociopolitical (politics, economics and society) issues. Based on the content analysis of key newspapers, this paper attempts to analyze the relationship between conflict and peace politics.

For testing the first objective on political discourse based on the conflict vs. peace politics, the research analyzed media news on Bosnia and Herzegovina by considering only socio-political topics. We randomly selected 120 news from 2014 to March 2016 from the following newspapers:

- Nezavisne novine (targets mainly Serbs as target group);

- $\quad$ Glas srpske (targets mainly Serbs as target group);

- Dnevni list (targets mainly Croats as target group);

- Dnevni avaz (targets mainly Bosniaks as target group). 
Analyzed socio-political news (politics, economics and society) in terms of their peace or conflict inclinations were determined based on their negative, extremely exclusive, positive and constructive contents. It is important to mention that this study does not compare newspapers in terms of their conflict vs. peace reporting. However, based on news, this paper aimed to identify main trends that reflect public socio-political discourses.

In order to examine the second objective on conflict vs. peace inclinations of political leaders, the research adopted similar methodology as in the above. We randomly selected interview-based news from 2014 to March 2016 given by each political leader from Nezavisne novine, Glas srpske, Dnevni list and Dnevni avaz. For the sake of political representation, the following leaders were selected: Bakir Izetbegović (Bosniak), Dragan Čović (Croat) and Milorad Dodik (Serb). Altogether, 360 news from these newspapers were anlyzed considering their peace or conflict contents inclinations.

\section{Data Presentations and Analysis}

In order to test the first objective on political discourse we used content analysis in analyzing media news on Bosnia and Herzegovina. We randomly selected news from Nezavisne novine, Glas srpske, Dnevni list and Dnevni avaz. In total, 120 news were selected in the span of last two years in terms of their peace or conflict inclination. News determined as negative were extremely exclusive by its title and content.

Table 1. Media reporting and news on Bosnia and Herzegovina

\begin{tabular}{|l|c|l|}
\hline Newspaper & $\begin{array}{l}\text { Positive } \\
\text { News }\end{array}$ & $\begin{array}{l}\text { Negative } \\
\text { News }\end{array}$ \\
\hline Dnevni list & $29 \%$ & $71 \%$ \\
\hline Dnevni avaz & $42 \%$ & $52 \%$ \\
\hline Nezavisne novine & $22 \%$ & $78 \%$ \\
\hline Glas srpske & $19 \%$ & $81 \%$ \\
\hline Average & $\mathbf{2 8 \%}$ & $\mathbf{7 1 \%}$ \\
\hline
\end{tabular}

According to analyzed news, Table 1 shows that in Dnevni list $71 \%$ of news were negative while $29 \%$ were positive. Analyzed news from Dnevni avaz were slightly different in terms of positive and negative news as this newspaper is pro-Bosnian newspaper. According to Dnevni avaz $52 \%$ of news were negative while $42 \%$ were positive. Then, Nezavisne novine included $78 \%$ of negative news and $22 \%$ of positive news. Finally, Glas srpske included $81 \%$ of negative news and $19 \%$ of positive news. Obtained data clearly indicated that conflict politics is deeply rooted in political discourse, the media and the public. 
Table 2. Content analysis of media reporting and news on Bosnia and Herzegovina (Selected news from 120 news)

\begin{tabular}{|c|c|c|}
\hline Newspaper & Negative News & Positive News \\
\hline $\begin{array}{c}\text { Nezavisne } \\
\text { novine }\end{array}$ & $\begin{array}{l}\text { - Server: For Serbia Bosnia is greater prob- } \\
\text { lem than Kosovo } \\
\text { Bosnia and Herzegovina is the most unfor- } \\
\text { tunate country in the region } \\
\text { - Slovakian TV: Bosnia and Herzegovina is } \\
\text { Serbian territory }\end{array}$ & $\begin{array}{l}\text { Covic: Bosnia and Herzegovina } \\
\text { will submit credible application for } \\
\text { EU membership on January } 16 \\
\text { Bosnia and Herzegovina: British- } \\
\text { German initiative }\end{array}$ \\
\hline Glas srpske & $\begin{array}{l}\text { Bosnia and Herzegovina imports even } \\
\text { bread } \\
\text { Bosnia and Herzegovina is placed at the } \\
\text { end of the list for EU expansion } \\
\text { ID wants new front and new fighters from } \\
\text { B\&H }\end{array}$ & $\begin{array}{l}\text { - } \quad \begin{array}{l}\text { Bosnia and Herzegovina accepted } \\
\text { border agreement with Montenegro }\end{array} \\
\text { Bosnia and Herzegovina has } \\
\text { signed EU program Horizon } 2020 \\
\text { accession }\end{array}$ \\
\hline Dnevni list & $\begin{array}{l}\text { - } \quad \text { Bosnia is cradle of modern jihad } \\
\text { Bosnia and Herzegovina definitely least } \\
\text { advanced (towards the EU) } \\
\text { Bosnia and Herzegovina is the greatest } \\
\text { threat to regional stability and security }\end{array}$ & $\begin{array}{l}\text { - } \quad \text { Bosnia and Herzegovina: British- } \\
\text { German initiative } \\
\text { Bosnia and Herzegovina will be } \\
\text { just multiethnic and employable } \\
\text { The following weeks are important } \\
\text { for European path of Bosnia and } \\
\text { Herzegovina }\end{array}$ \\
\hline Dnevni avaz & $\begin{array}{l}\text { - Izetbegovic at Summit in Istanbul: Bosnia } \\
\text { is under attack of radical interpretation of } \\
\text { Islam } \\
\text { Bosnia in danger: Vučić threatens and } \\
\text { Bakir returns } \\
\text { - Nikolic: Bosnia looks like a sick man }\end{array}$ & $\begin{array}{l}\text { Wigemark: Bosnia and Herzegovi- } \\
\text { na after ten years EU member } \\
\text { Zvizdic-Schultz: Bosnia and Her- } \\
\text { zegovina enjoys significant support } \\
\text { of European parliament } \\
\text { Zvizdic: Bosnia is strongly moving } \\
\text { forward }\end{array}$ \\
\hline
\end{tabular}

For the sake of examining conflict and peace inclinations of political leaders, we randomly selected news about Bakir Izetbegović, Dragan Čović and Milorad Dodik. By using content analysis, we analyzed 90 interview-based news from Nezavisne novine in order to determine their positive or negative inclinations.

Table 3. Nezavisne novine on conflict vs. positive views of political leaders

\begin{tabular}{|l|c|c|}
\hline Political Leader & Conflict Views & Positive Views \\
\hline Bakir Izetbegovic & $29 \%$ & $71 \%$ \\
\hline Dragan Čović & $42 \%$ & $58 \%$ \\
\hline Milorad Dodik & $91 \%$ & $9 \%$ \\
\hline
\end{tabular}

According to Table 3 and analysis of randomly selected news from Nezavisne novine, key political leaders expressed themselves as follows: Bakir Izetbegovic $71 \%$ positive views and 29\% negative; Dragan Čović 58\% positive and 42 negative and Milorad Dodik 9\% positive and 91\% negative. Overall findings indicate that Izetbegovic and Čović were using positive views while discussing different socio-political issues in their interviews. On the other hand, Milorad Dodik had only $9 \%$ of positive views while discussing similar topics and 91\% negative or conflict-based. Nezavisne novine presented his conflict or exclusive statements although this newspaper targets Serbs as its main target group. In this regard, it is important to mention unbiased and objective reporting by this newspaper. This also shows that conflict or peace doesn't originate with media but from political leaders whose views, positive or negative are just reported to the public. 
Table 4. Content analysis of Nezavisne novine on conflict vs. positive views of political leaders (Selected news from 90 news)

\begin{tabular}{|c|c|c|}
\hline Newspaper & Negative News & Positive News \\
\hline Nezavisne novine & $\begin{array}{l}\text { Izetbegovic: Vučić shouldn’t worry about } \\
\text { B\&H but let him influence Banja Luka } \\
\text { Izetbegovic: Dodik's behavior cannot be } \\
\text { justified } \\
\text { - } \quad \text { Izetbegovic: We will not tolerate treats } \\
\text { from Belgrade } \\
\text { Dragan Covic: HDZ will not tolerate } \\
\text { Bosnjak government } \\
\text { - } \quad \text { Dragan Čovic: The future of B\&H in four } \\
\text { territorial units } \\
\text { Dragan Čovic: Social protests want to use } \\
\text { for political purposes } \\
\text { - Milorad Dodik: B\&H is a forced country } \\
\text { Milorad Dodik: Pamer is live example that } \\
\text { Bosnia and Herzegovina is not serious } \\
\text { country } \\
\text { Milorad Dodik: We don’t want foreigners } \\
\text { in negotiations }\end{array}$ & $\begin{array}{l}\text { Bakir Izetbegovic: Opening } \\
\text { of Ferhadija (mosque) is the } \\
\text { victory of life } \\
\text { Izetbegovic: Bosnjak politi- } \\
\text { cians don't request termination } \\
\text { of RS } \\
\text { Izetbegovic: Nikolic in March } \\
\text { in Bosnia and Herzegovina } \\
\text { Dragan Čovic: Next year } \\
\text { candidacy status } \\
\text { Dragan Čovic: We must strive } \\
\text { on the European path } \\
\text { Dragan Čovic: United we can } \\
\text { achieve our objectives } \\
\text { Milorad Dodik: Serbs and } \\
\text { Bosnaks must build good } \\
\text { relations } \\
\text { Milorad Dodik presented } \\
\text { gifts for newly built Ferhadija } \\
\text { mosque } \\
\text { Milorad Dodik: Corrupted } \\
\text { people have no place in public } \\
\text { administration }\end{array}$ \\
\hline
\end{tabular}

The conflict and peace inclinations of political leaders, using same methodology as in the above, were analyzed 90 interview-based news on key political leaders from newspaper Glas srpske.

Table 5. Glas srpske on conflict vs. positive views of political leaders

\begin{tabular}{|l|c|c|}
\hline Political Leader & Conflict Views & Positive Views \\
\hline Bakir Izetbegovic & $26 \%$ & $74 \%$ \\
\hline Dragan Čović & $19 \%$ & $81 \%$ \\
\hline Milorad Dodik & $96 \%$ & $4 \%$ \\
\hline
\end{tabular}

According to Table 5 and analysis of randomly selected news from Glas srpske, key political leaders expressed themselves as follows: Bakir Izetbegovic $74 \%$ positive views and 26\% negative; Dragan Čović 81\% positive and 19 negative and Milorad Dodik 4\% positive and 96\% negative. Overall findings based on analysis of Glas srpske newspaper indicate that both Izetbegovic and Čović had positive views while addressing different socio-political issues in their interviews while Milorad Dodik, as in the above based on Nezavisne novine analysis, was expressing extremely negative views on sociopolitical issues. Glas srpske is another newspaper that is pro-Serb in reporting. However, this paper shows objective reporting on key political leaders based on their own peace or conflict political approaches. 
Table 6. Content analysis of Glas srpske on conflict vs. positive views of political leaders (Selected news from 90 news)

\begin{tabular}{|c|c|c|}
\hline Newspaper & Negative News & Positive News \\
\hline Glas srpske & $\begin{array}{l}\text { Bakir Izetbegovic: The decision on refer- } \\
\text { endum must be repealed } \\
\text { Bakir Izetbegovic: Respect towards vic- } \\
\text { tims and then peace and conciliation } \\
\text { Bakir Izetbegovic: A clash between two } \\
\text { laws/rights will be resolved by war } \\
\text { Dragan Čović: We are paying the price for } \\
\text { playing with the formation of government } \\
\text { Dragan Čović: We do not accept condi- } \\
\text { tions on pretext of protests } \\
\text { Dragan Cović: Investigators should talk } \\
\text { less and work more } \\
\text { Milorad Dodik: Izetbegovic is guilty for } \\
\text { the war in B\&H } \\
\text { Milorad Dodik: Bosnjaks intend to ma- } \\
\text { nipulate results } \\
\text { Milorad Dodik: RS will announce census } \\
\text { results }\end{array}$ & $\begin{array}{l}\text { Bakir Izetbegovic: Integration in the } \\
\text { EU a way for achieving stability } \\
\text { Bakir Izetbegovic: Vučić is humble } \\
\text { leader who offers his hand } \\
\text { Bakir Izetbegovic: I am ready to } \\
\text { visit places of Serb suffering } \\
\text { Dragan Čović: Cooperation with the } \\
\text { region priority } \\
\text { Dragan Čović: We are able to } \\
\text { - } \quad \text { resolve our problems alone } \\
\text { Dragan Čović: Preserve political } \\
\text { stability and coalition } \\
\text { Milorad Dodik: We are ready for the } \\
\text { elections but at all levels } \\
\text { Milorad Dodik: Dodik presented his } \\
\text { loan contract } \\
\text { Milorad Dodik: Key question pre- } \\
\text { serving peace and security in } 2016\end{array}$ \\
\hline
\end{tabular}

The conflict and peace inclinations of political leaders, using same methodology as in the above, were also based on newspaper Dnevni list.

Table 7. Dnevni list on conflict vs. positive views of political leaders

\begin{tabular}{|l|c|c|}
\hline \multicolumn{1}{|l|}{ Political Leader } & Conflict Views & \multicolumn{1}{c|}{ Positive Views } \\
\hline Bakir Izetbegovic & $64 \%$ & $36 \%$ \\
\hline Dragan Čović & $38 \%$ & $62 \%$ \\
\hline Milorad Dodik & $32 \%$ & $68 \%$ \\
\hline
\end{tabular}

According to Table 7 and analysis of randomly selected news from Dnevni list, key political leaders expressed themselves as follows: Bakir Izetbegovic 36\% positive views and 64\% negative; Dragan Čović 62\% positive and 38 negative and Milorad Dodik $68 \%$ positive and $32 \%$ negative. It is important to mention that Dnevni list is Croat oriented newspaper. It is very much visible through emphasis on news mostly related to Croat-Bosniak relations in $\mathrm{FBiH}$. Perhaps this is one of the reasons why positive news are reported on entity RS and their leader Milorad Dodik. Dnevni list presented mostly positive views of Dragan Čović (62\%) in comparison to Bakir Izetbegovic (64\%) whose views were mostly negative. Data also indicated that Bosniak-Croat relations are partially based on conflict rather than peace politics. 
Table 8. Content analysis of Dnevni list on conflict vs. positive views of political leaders (Selected news from 90 news)

\begin{tabular}{|c|c|c|}
\hline Newspaper & Negative News & Positive News \\
\hline Dnevni list & $\begin{array}{l}\text { Bakir Izetbegovic: Be on the right side this } \\
\text { is my offer } \\
\text { Bakir Izetbegovic: There are no positive } \\
\text { developments in Mostar } \\
\text { Bakir Izetbegovic: Nothing can improve } \\
\text { relations between Serbia and Bosnia and } \\
\text { Herzegovina } \\
\text { Dragan Čović: With Izetbegovic, there are } \\
\text { no more meetings on Mostar } \\
\text { Dragan Čović: It is necessary to organize } \\
\text { B\&H based on four territorial units } \\
\text { Dragan Čović: Covic was threatening with } \\
\text { new partners } \\
\text { Milorad Dodik: Bosnian language doesn't } \\
\text { exist } \\
\text { Milorad Dodik: Genocide in Srebrenica } \\
\text { didn't take place } \\
\text { Milorad Dodik: resign and I will call for } \\
\text { new elections }\end{array}$ & $\begin{array}{l}\text { Bakir Izetbegovic: It is necessary } \\
\text { to talk to all } \\
\text { Bakir Izetbegovic: Coalition is } \\
\text { stable } \\
\text { Bakir Izetbegovic: Prosperous } \\
\text { B\&H is main objective of SDA } \\
\text { Dragan Čović: I called Pope to visit } \\
\text { B\&H } \\
\text { Dragan Čović: This is our country } \\
\text { and here we will stay and live } \\
\text { Dragan Čović: I believe that elec- } \\
\text { tions will be organized in Mostar } \\
\text { Milorad Dodik: RS is not against } \\
\text { EU: As soon as possible resolve } \\
\text { mechanism of coordination } \\
\text { Milorad Dodik: Serbs will not go } \\
\text { to war } \\
\text { Milorad Dodik: Dodik bowed } \\
\text { down to the victim of genocide in } \\
\text { Srebrenica }\end{array}$ \\
\hline
\end{tabular}

The conflict and peace inclinations of political leaders, using same methodology as in the above, were also based on newspaper Dnevni avaz.

Table 9. Dnevni avaz on conflict vs. positive views of political leaders

\begin{tabular}{|l|c|c|}
\hline Political Leader & Conflict Views & Positive Views \\
\hline Bakir Izetbegovic & $32 \%$ & $68 \%$ \\
\hline Dragan Čović & $26 \%$ & $74 \%$ \\
\hline Milorad Dodik & $79 \%$ & $21 \%$ \\
\hline
\end{tabular}

According to Table 9, Dnevni avaz presented views of key political leaders as follows: Bakir Izetbegovic $68 \%$ positive views and 32\% negative; Dragan Čović 74\% positive and $26 \%$ negative and Milorad Dodik $21 \%$ positive and $79 \%$ negative. Dnevni list is Bosniak oriented newspaper. Besides Nezavisne novine and Glas srpske newspapers, Dnevni avaz also indicated that Milorad Dodik represented mostly conflict views on different socio-political issues. 
Table 10. Content analysis of Dnevni avaz on conflict vs. positive views of political leaders (Selected news from 90 news)

\begin{tabular}{|c|c|c|}
\hline Newspaper & Negative News & Positive News \\
\hline Dnevni avaz & $\begin{array}{l}\text { Bakir Izetbegovic: Vučić should work on } \\
\text { the reconciliation and not on making quick } \\
\text { statements } \\
\text { Bakir Izetbegovic: We are attacked by } \\
\text { those who are fighting for their positions } \\
\text { Bakir Izetbegovic: Dodik's accusations } \\
\text { are meaningless, I would prefer if they } \\
\text { postpone protests } \\
\text { Dragan Čović: The path of dominant } \\
\text { Bosnak entity is ill-favored politics } \\
\text { Dragan Čović: We do not give up six posi- } \\
\text { tions, ours is the Ministry of Finance } \\
\text { Dragan Čović: We cannot be the coalition } \\
\text { if we don't have common stand } \\
\text { Milorad Dodik: Incko is not right, RS do } \\
\text { not violate Dayton } \\
\text { Milorad Dodik: After Scotland RS should } \\
\text { get ready! } \\
\text { Milorad Dodik: We will hold referendum } \\
\text { for independence }\end{array}$ & $\begin{array}{l}\text { Bakir Izetbegovic: SDA and SBB } \\
\text { will have the solution for Mostar } \\
\text { Bakir Izetbegovic: Croat question } \\
\text { could be solved in the first half } \\
\text { of } 2016 \\
\text { Bakir Izetbegovic: Holy Eucharist } \\
\text { reminds us of splendor of diversity } \\
\text { Dragan Čović: B\&H must follow } \\
\text { European standards } \\
\text { Dragan Čović: We have shown the } \\
\text { way of how to love our country } \\
\text { Dragan Čović: European path is } \\
\text { again open for B\&H } \\
\text { Milorad Dodik: Giving the chance } \\
\text { for structural dialogue in Brussels } \\
\text { Milorad Dodik: RS is good and } \\
\text { stable place to live regardless to } \\
\text { religion and nationality } \\
\text { Milorad Dodik: Radoncic's le- } \\
\text { gitimacy should be respected and } \\
\text { appreciated }\end{array}$ \\
\hline
\end{tabular}

\section{Conclusions and Recommendations}

Centuries old multicultural paradigm in Bosnia and Herzegovina was replaced with ethno-cultural paradigm due to the war and its implications. Exclusive ethnic ideologies, coupled with the international tutelage and ineffective political approaches in Bosnia and Herzegovina, produced permanent crisis and the status quo. Actually, ethno-cultural paradigm was furthermore enforced and pre-war culture of accountability, peace, dialogue and compromise were replaced with socio-political conflict based on fear and distrust. Due to these reasons, this paper attempted to put in the perspective peace vs. conflict politics. Indeed, it is significant to articulate the politics of peace, cooperation and soft diplomacy, because the creation of the positive socio-political environment is the precondition for Bosnian stability and regional peace and cooperation.

In spite of past and present socio-political predicaments, Bosnia-Herzegovina as a microcosmic multicultural model represents an increasingly interconnected and diverse world. Bosnian multicultural paradigm counters the perspective of Huntington's clash of civilizations. Therefore, multicultural paradigm is not only central to the rebuilding and transition of Bosnia-Herzegovina but to the global world as a whole. Bosnia-Herzegovina managed to incorporate ethnic, religious and cultural diversities, projecting a distinctive multicultural state identity. Being a multicultural state, Bosnia-Herzegovina has always flourished as a part of a greater whole. Therefore, the future of this small country lies in joining the EU, a family of nations that uphold diversity. Upholding liberal values, cosmopolitan multiculturalism, the Tradition and diverse socio-cultural values derived from Bosnia's past and present would in turn uphold and strengthen the EU road towards achieving the goal of creating a family of nations.

Based on the results from this study on political discourse and political relationships in terms of the conflict vs. peace politics we strongly believe that exclusive political approaches based on rigidity and conditioning, inherited from the war, could 
be substituted with the real politics, politics of peace and cooperation. Therefore, we propose the following recommendations: political incorporation of ethnic, religious and cultural diversities; promotion of a distinctive multicultural state identity; promotion of scholarship and research on the relationship between conflict and peace politics; fostering peace/constructive not conflict/destructive approaches by leaders; and supporting political parties and leaders that use peace politics in Bosnia and Herzegovina.

\section{References}

Batora, Jozef and Mokre, Monika (Eds.) (2011). Culture and External Relations: Europe and Beyond. Oxon: Ashgate.

Bechev, Dimitar. (2011). Constructing South East Europe: The Politics of Balkan Regional Cooperation. New York: Palgrave Macmillan.

Cohen, J. Lenard. (1995). Broken bonds: Yugoslavia's disintegration and Balkan politics in Transition Boulder - Colorado: Westview Press.

Džihić, V., \& Wieser, A. (2011). Incentives for Democratisation? Effects of EU Conditionality on Democracy in Bosnia \& Herzegovina. Europe-Asia Studies, 63 (10).

Dnevni avaz. http://www.avaz.ba/

Dnevni list. http://dnevni-list.ba/web1/

Glas Srpske. http://www.glassrpske.com/

Holbrooke, Richard. (1998). To End a War. Random House inc.

Mahmutćehajić, Rusmir. (2000). Sarajevski eseji: Politika, ideologija i tradicija. Zagreb: Durieux.

Mulalic, Muhidin. (2014). "Socio-Cultural Dimension of Bosnia and Herzegovina," in Mesut Idriz and Osman Bakar (Eds.) Islam in Southeast Europe: Past Reflections and Future Prospects. UBD Press, Brunei. pp. $55-67$

Mulalic, Muhidin. (2013). "Balkans Image, Geopolitics and Interdependence." In Muhidin Mulalic, Hasan Korkut and Elif Nuroglu, (Eds). Turkish-Balkans Relations: The Future Prospects of Cultural, Political and Economic Transformations and Relations. Istanbul.

Mulalic, Muhidin. (2009). "Multiculturalism and EU Enlargement: The Case of Turkey and Bosnia-Herzegovina." In Christoph Marcinkowski ed., The Islamic World and the West: Managing Religious and Cultural Identities in the Age of Globalisation. LIT Verlag Berlin.

Mujkic, Asim. (2007). Mi gradjani etnopolisa. Sarajevo: Sahinpasic.

Nezavisne novine. http://www.nezavisne.com/

Nye, J. S. (2004). Power in the Global Information Age. New York: Routledge.

Parish, Matthew. (2011). "Comment: Croat Crisis Pushes Bosnia Towards Endgame,"

Balkan Insight, http://www.balkaninsight.com /en/arti-cle/comment-croat-crisis-pushes-bosnia-towardsendgame.

Perry Valery. (2005). "Ethnic Democracy in Bosnia and Herzegovina: Containing the Spectre?," in The fate of ethnic democracy in post-communist Europe, ed. Sammy Smooha and Priit Jarve, vol. 3. Flensburg: The European Centre for Minority Issues. pp. 209-239.

Šarčević, Edin. (2009). Dejtonski ustav: karakteristike i problem. Ljubljana: IFIMES.

Trnka, Kasim. (2000). Ustavno pravo. Sarajevo. 